ratory and with IRMA in another. In I972-1973 the samples were investigated with Prot-oMat in two laboratories.

In each year there appeared significant differencies in protein-p. Ioo between laboratories but these grew continuously smaller. These differencies like the effects of days after calving, of average herd milk yield and of month of test day were eliminated with statistical corrections prior to estimating the heritabilities and progeny testing, Daughter's fat-p. Ioo, milk yield of test day, protein/fat-ratio and fat and protein yields of test day were computed in the same way.

The heritabilities of different traits on the basis of one test day were as follows : milk yield 25 p. Ioo, fat-p. I00 28 p. I00, protein-p. I00 25 p. Ioo, protein/fat-ratio r7 p.I00, fat yield $2 \mathrm{I}$. IOo, protein yield $19 \mathrm{p}$. IOo and fat + protein yieid $2 \mathrm{I} \mathrm{p}$. IOo. The estimates varied slightly in each year; it seems that the most reliable estimates were from the year I973. On the basis of the mentioned heritabilities the number of daughters required for a repeatability of $70 \mathrm{p}$. 1 00 in progeny testing were $35,3 \mathrm{r}, 3.5,53,42,47$ and 42 respectively. In the number of samples these mean 20-30 p. Ioo of what is needed to reach the same accuracy with a monthly sample of 16 daughters during lactation. Progeny tests based on at least ten daughters were obtained from 136 , I 34 and I 56 bulls each year respectively. It seems as though with a relatively small number of samples the progeny testing of bulls can be managed.

In the progeny testing results the correlation of milk yield with fat-p. Ioo was -0.42 , with protein-p. Ioo -0.29 , with fat yield $0.8 \mathrm{I}$, and with protein yield $0.9 \mathrm{I}$. The correlation between fat-p. roo and protein-p. roo was 0.44 , and between fat yield and protein yield 0.84 . The genetic correlations calculated from single observations were similar to these both for signs and values.

\title{
SERUM ENZYMES AND METABOLITES RELATED WITH HIGH PRODUCTION AND LONGEVITY
}

F. Graf, K. Frahm, L. Furtmayr, H. Kräusslich, K. Osterkorn. - Institut für Tievzucht und Tierhygiene der Ludwig-Maximilians Universität München, Veterinärstr. 22, 8, München 22, $B R D$.

Metabolites and enzymes in the blood which are normally used for clinical diagnoses (total bilirubin, glucose, cholesterol, GOT, CK LDH and LDH-isoenzymes), were regularly determined in a high yielding dairy herd, during all stages of lactation. The correlations between serum levels and the dairy traits were analysed.

What we are really looking for by analysing these correlations is to find indicators for the individual physiological reactions of dairy cows on the stress caused by a very high milk production. We think that physiological differences between high yielding cows do exist. There might be cows with a very stabile organism which easily give a high yield, and others which are suffering much more by the stress caused by the production of the same amount of milk.

The investigations were carried out during a period of two years in the dairy herd of the University of Munich consisting of about roo Holstein-Friesian cows. The average milk yield amounted to 7 ooo $\mathrm{kg}$ milk per year with $3.87 \mathrm{p}$. Ioo butterfat. Each cow was bled 8 weeks before parturition, I week before parturition, 6-24 hours after parturition, 1, 2, 3, 5 weeks after parturition and afterwards in intervals of 8 weeks. The serum levels of all examined blood constituents were significantly influenced by diseases, age, season and stage of lactation. The influence of diseases was eliminated by only analysing data taken from samples of cows which showed no signs of disease. The influence of season was accounted for by adjustment factors. To avoid biases caused by differences in age and stage of lactation intraclass correlations for different stages of lactation were calculated within age classes.

Numerous significant correlations between the serum levels and the milk yield (milk kg, FCM, fat-p. Ioo, fat $\mathrm{kg})$ at different stages of lactation were found $(r=0.23-0.6 \mathrm{I})$.

For all parameters, rank correlations were calculated. The ranking was determined by the deviations of the measured serum levels from the regression line relating milk yield and serum level. Significant rank correlations between glucose and GOT, cholesterol and glucose and between GOT and LDH-isoenzymes $1+2$ were detected.

The correlations between the serum levels of two successive lactations were calculated as measurements of the repeatability of the different parameters. Some parameters showed close correlations. In all stages of lactation glucose had the closest correlations of all the parameters examined (up to 0.997). The serum levels of glucose and cholesterol samples, taken 8 weeks before parturition when they are nearly uninfluenced by the milk yield, were about Io p. Ioo higher in animals selected than in animals culled during second lactation. However, the difference is not significant. The other parameters showed no differences between selected and culled animals. 